\title{
Molecular genetic analysis of Steroid Resistant Nephrotic Syndrome: Detection of a novel mutation
}

\author{
Niloofar Serajpour ${ }^{*}$, Behnaz Karimi ${ }^{\dagger}$, Nakisa Hooman ${ }^{\ddagger}$, Rozita Hosseini ${ }^{\ddagger}$, Pedram Khosravi $^{\dagger}$, Hila \\ Milo Rasouly ${ }^{\S}$, Azadeh Shojaei ${ }^{*}, 1$ \\ *: Department of Medical Genetics and Molecular Biology, Faculty of Medicine, Iran University of Medical \\ Sciences, Tehran, Iran \\ $\dagger$ : Medical Genetic laboratory, Shahid Akbarabad hospital, Iran University of Medical science, Tehran, Iran. \\ 7: Department of Pediatric Nephrology, Ali-Asghar Children Hospital, Iran University of Medical Sciences, \\ Tehran, Iran. \\ $\S$ : Division of Nephrology, Columbia University College of Physicians and Surgeons, 1150 Saint Nicholas \\ Avenue, Russ Berrie Pavilion \#412C, New York, New York 10032, USA. \\ 1Correspond author: Department of Medical Genetics and Molecular Biology, Faculty of Medicine, Iran \\ University of Medical Sciences, Tehran, Iran. Address: Iran University of Medical Sciences, Shahid \\ Hemmat Highway,Tehran, 1449614535, IRAN. P.O Box: 14665-354. Email: a_shojaei2007@yahoo.com. \\ Tell: +98-21- 86709
}

\section{ABSTRACT}

Background: Nephrotic syndrome is one of the most common kidney diseases in childhood. About $20 \%$ of children are steroid-resistant NS (SRNS) which progress to end-stage renal disease (ESRD). More than 53 genes are associated with SRNS which represent the genetic heterogeneity of SRNS. This study was aimed to screen disease causing mutations within NPHS1 and NPHS2 and evaluate new potential variants in other genes.

Method: In first phase of study, 25 patients with SRNS were analyzed for NPHS1 (exon 2, 26) and all exons of NPHS2 genes by Sanger sequencing. In the second phase, whole exome sequencing was performed on 10 patients with no mutations in NPHS1 and NPHS2.

Result: WES analysis revealed a novel mutation in FAT1 (c.10570C>A; Q3524K). We identified 4 pathogenic mutations, located in exon 4 and 5 of NPHS2 gene in $20 \%$ of patients (V180M, P118L, $\mathrm{R} 168 \mathrm{C}$ and Leu156Phe). Also our study has contributed to the descriptions of previously known pathogenic mutations across WT1 (R205C) and SMARCAL1 (R764Q) and a novel polymorphism in CRB2.

Conclusion: Our study concludes that mutations of exon 4 and 5 NPHS2 gene are common in Iranian and some other ethnic groups. We suggest conducting WES after NPHS2 screening and further comprehensive studies to identify the most common genes in the development of SRNS, which might help in Clinical impact on management in patients with SRNS. 


\section{Detection of a novel mutation in SRNS}

\section{INTRODUCTION}

Nephrotic Syndrome (NS) is one of the most common idiopathic primary diseases in childhood.(Bierzynska and Saleem 2017; Ha 2017; Weber et al. 2004) Which is defined as presence of four main symptoms: proteinuria, hyperlipidemia, hypoalbuminemia and edema (Bullich et al. 2015; Joshi et al. 2013). According to the patient's response to the steroid therapy the disease divided into: resistant and sensitive groups. About $90 \%$ of patients are responsive to steroid therapy during four weeks who called steroid sensitive nephrotic syndrome (SSNS). Patients in whom proteinuria does not stop after about one month are classified as resistant which describe as steroid resistant nephrotic syndrome(SRNS)(Mekahli et al. 2009).SRNS is considered as a poor prognostic disease, in which $30-40 \%$ of it progresses to end stage renal disease(ESRD), requiring dialysis and transplantation(Tasic et al. 2015). The most frequent renal histological feature associated with SRNS is focal segmental glomerulosclerosis (FSGS). Moreover minimal change nephrotic syndrome (MCNS), and diffuse mesangial sclerosis (DMS) have been identified (Santin et al. 2009; Hinkes et al. 2007; Ha 2017). Genetic forms of SRNS are classified as isolated kidney disease or syndromic disorder (Ha 2017)The fenestrated endothelium, the glomerular basement membrane (GBM) and the podocytes form three layers of glomerular filtration barrier (GFB) which is impaired in NS and cause proteinuria.(Haraldsson et al. 2008)

2major proteins of podocytes including nephrin and podocin, coded by NPHS1 and NPHS2, are considered to play an important role in GFB. Mutations in these genes result in altering conformation and stability of podocytes and causing proteinuria and SRNS(Huber et al. 2003). Most cases of SRNS are considered as sporadic representing both AR and AD inheritance. NPHS1 and NPHS2 genes are the most common identified genes in AR form (Wang et al. 2017; Lovric et al. 2014). 
This study was aimed to screen mutations causing disease within NPHS1 and NPHS2, figuring out the most common mutations in Iranian children and comprising the prevalence of such mutations among different nations. Due to heterogeneity of this disease, WES was performed for 10 patients in pilot study to evaluate other related genes and exploring new potential mutations. Indeed, preventing of ineffective treatment with steroids and helping proper clinician prediction in post transplantation outcome may be facilitated via indicating the specific mutations.

\section{MATRIALS AND METODS}

\subsection{Patients' description}

25 subjects were recruited from Ali_Asghar children's hospital in Tehran, Iran. The enrollment of patients in this study is based mainly on the clinical diagnosis of SRNS and disease onset ages varying from congenital to childhood. 3 of the children have been progressed into an end-stage renal disease and 5 of patients are undergoing dyalisis .The informed consent forms were given by parents of patients. The study was approved by the Ethical Committee of "Iran University of Medical Sciences, Faculty of Medicine".

\subsection{Polymerase chain reaction $(\mathrm{PCR})$ and sequencing:}

$4 \mathrm{ml}$ of whole blood was taken from Patients and was transferred into tubes containing $200 \mu \mathrm{L}$ EDTA for DNA isolation. DNA was isolated from peripheral blood of all samples by yekta tajhiz azma (YTA) kit (Iran).

All exons of NPHS2 gene were screened (primers are available upon request).exons 2 and 26 of NPHS1 gene were amplified using four primer pair (Supplementary data). Subsequently, to confirm the identified mutations in affected children, their parents were studied as well. 
Reaction were accomplished in a total volume of $25 \mu \mathrm{L}$ containing $12.5 \mu 1$ Master Mix (Amplicon with $1.5 \mathrm{mM} \mathrm{MgCl} 2$ ), $11 \mu \mathrm{l}$ DEPC water, 20_40 ng template DNA and 10 pmol from each primer as well.

After initial denaturation at $94{ }^{\circ} \mathrm{C}$ for $3 \mathrm{~min}, 35 \mathrm{PCR}$ cycles was performed using Thermofisher thermocycler thermocycler (SimpliAmp ${ }^{\mathrm{TM}}$ Thermal Cycler 96-well, Applied Bio systems); each cycle included denaturation at $94^{\circ} \mathrm{C}$ in $30 \mathrm{~s}$, annealing tempature at 62 for exon 2,26 . extension at $72^{\circ} \mathrm{C}$ for $30 \mathrm{~s}$ and final extension at $72^{\circ} \mathrm{C}$ in $5 \mathrm{~min}$.

PCR products were subjected to electrophoresis on agarose gel (1.5\%).Sequencing was done by MACROGEN Company in South Korea using classic Sanger method with ABI. obtained sequences were aligned to the reference genome by chromas software and blast in Refseq in ncbi.

\subsection{Whole exome sequencing (WES):}

The second phase of study, WES was carried out for 10 patients by Colombia University Medical Center, IGM Institute for Genomic Medicine, Hemer Health Science.

\section{RESULT:}

\subsection{Polymerase chain reaction (PCR) and sequencing:}

25 children with SRNS were referred to Ali-Asghar hospital in Tehran, Iran to be examined for mutational analysis. Their mean age at the onset of symptoms was $(2.54 \pm 3.24)$ years (congenital to 14 years Positive family history was detected in 4 patients (16\%), while 21 patients were sporadic $(84 \%)$ in this cohort. Renal biopsy of patients indicated four different conditions, including FSGS (44\%), MCNS (28\%), CNF (8\%), MeSPGN (4\%).Histological data of 3 patients were not available. Also 9 patients showed positive family history of kidney stone. (Table.1)

We identified c.567.568insT known pathogenic frameshift mutation (L156fsx166) in 2 patients. Moreover c.502C > T (p.168R >C) pathogenic homozygous mutation was found in one patient. Both 
of these mutations were located in exon 4 of NPHS2 gene. parents were screened for these mutations.(Figure 1) Although no mutation causing disease was detected in the other studied exons of NPHS1 and NPHS2 genes by this method, but benign or likely benign variants were detected in 15 patients (56\%) within these regions.(Table.3)

\subsection{Whole exome sequencing (WES):}

To investigate other related genes and confer higher detection rate, WES was performed for 10 patients, with negative findings in the first phase of study. Two pathogenic mutations in NPHS2 were found in exon 2 and 5. Also, two other causative mutations were identified within WT1 and SMARCAL1 genes in 2 patients. Significantly, a novel mutation in FAT1 was detected. To predict the clinical significance of the found mutations, 3 different softwares were used, including SIFT, Polyphen, mutation assessor which revealed the prediction score of $0.034,0.044$ and 2.1, respectively. (Table.2). Moreover, the parents of this patient were sequenced by PCR for confirmation of the novel mutation.( Figure 2) To amplify this region a specific primer pair was designed by primer3plus.(Supplementary data) Another novel variant were found in CRB2 predicted to be " benign" by the above-mentioned silico analysis softwares. $(0.058,0.671$, $)$ (Table.3) .

Table 1. Clinical data of SRNS patients

\begin{tabular}{|c|c|c|c|c|c|c|}
\hline $\begin{array}{l}\text { Patient } \\
\text { number }\end{array}$ & Gender & $\begin{array}{l}\text { Sporadic/ } \\
\text { Familial }\end{array}$ & $\begin{array}{l}\text { Age at onset } \\
\text { (years/month) }\end{array}$ & $\begin{array}{l}\text { Renal } \\
\text { biopsy }\end{array}$ & consanguinity & $\begin{array}{l}\text { Family } \\
\text { history of } \\
\text { kidney } \\
\text { stone }\end{array}$ \\
\hline $\mathbf{P 1}$ & $\mathrm{F}$ & Sporadic & $3 Y$ & MCNS & $\mathrm{NO}$ & $\mathrm{NO}$ \\
\hline $\mathbf{P 2}$ & $\mathrm{F}$ & familial & $2 \mathrm{Y}$ & FSGS & YES & YES \\
\hline $\mathbf{P 3}$ & $\mathrm{M}$ & sporadic & CONGENITAL & FSGS & $\mathrm{NO}$ & $\mathrm{NO}$ \\
\hline
\end{tabular}




\begin{tabular}{|c|c|c|c|c|c|c|}
\hline $\mathbf{P 4}$ & $\mathrm{M}$ & sporadic & $2 \mathrm{Y}$ & FSGS & YES & YES \\
\hline P5 & $\mathrm{F}$ & familial & $4 Y$ & FSGS & $\mathrm{NO}$ & YES \\
\hline P6 & $\mathrm{F}$ & sporadic & $1.5 \mathrm{Y}$ & FSGS & YES & $\mathrm{NO}$ \\
\hline P7 & $\mathrm{F}$ & sporadic & $10 Y$ & MeSPGN & YES & YES \\
\hline P8 & $\mathrm{F}$ & sporadic & $2 \mathrm{Y}$ & MCNS & YES & $\mathrm{NO}$ \\
\hline P9 & $\mathrm{M}$ & sporadic & $10 \mathrm{M}$ & FSGS & YES & YES \\
\hline P10 & $\mathrm{F}$ & familial & $7 Y$ & MCNS & YES & YES \\
\hline P11 & $\mathrm{M}$ & sporadic & $3 Y$ & - & YES & $\mathrm{NO}$ \\
\hline P12 & $\mathrm{F}$ & sporadic & $2 \mathrm{Y}$ & FSGS & YES & YES \\
\hline P13 & $\mathrm{F}$ & sporadic & $2 \mathrm{Y}$ & FSGS & $\mathrm{NO}$ & $\mathrm{NO}$ \\
\hline P14 & $\mathrm{F}$ & sporadic & $3 \mathrm{Y}$ & MCNS & YES & $\mathrm{NO}$ \\
\hline P15 & $\mathrm{M}$ & sporadic & $2.5 \mathrm{Y}$ & MCNS & $\mathrm{NO}$ & $\mathrm{NO}$ \\
\hline P16 & $\mathrm{F}$ & sporadic & CONGENITAL & CNS & YES & YES \\
\hline P17 & $\mathrm{M}$ & sporadic & $2 \mathrm{Y}$ & MCNS & YES & YES \\
\hline P18 & $\mathrm{F}$ & sporadic & $1 \mathrm{Y}$ & - & YES & YES \\
\hline P19 & $\mathrm{F}$ & sporadic & $5 \mathrm{M}$ & MCNS & YES & YES \\
\hline P20 & M & sporadic & CONGENITAL & - & YES & YES \\
\hline P21 & M & sporadic & $6 \mathrm{M}$ & FSGS & YES & YES \\
\hline $\mathbf{P 2 2}$ & $\mathrm{M}$ & sporadic & CONGENITAL & CNS & YES & $\mathrm{NO}$ \\
\hline $\mathbf{P 2 3}$ & $\mathrm{F}$ & familial & CONGENITAL & - & YES & YES \\
\hline P24 & $\mathrm{F}$ & sporadic & $8 \mathrm{M}$ & FSGS & YES & YES \\
\hline $\mathbf{P 2 5}$ & $\mathrm{M}$ & sporadic & $14.5 \mathrm{Y}$ & FSGS & $\mathrm{NO}$ & YES \\
\hline
\end{tabular}


Table2. Found pathogenic mutations in the 5 patients with SRNS by WES

\begin{tabular}{|l|l|l|l|}
\hline Gene & cDNA ID & Variants & rs\# or chr position \\
\hline NPHS2 & NM_014625.3 & c.538G $>$ A , V180M & Chr1-179526362:C/T \\
\cline { 3 - 4 } & & c.353C >T , P118L & Chr1-179533850:G/A \\
\hline SMARCAL1 & NM_014140.3 & c.2291G>A, R764Q & Chr2-217340038:G/A \\
\hline WT1 & NM_024426.4 & c.1300C >T, R205C & Chr11-32414251:G/A \\
\hline FAT1 & NM_005245.3 & c.10570C>A ,Q3524K & Chr4-187525110:G/T \\
\hline
\end{tabular}

Table3. Found SNP in the 15 patients with SRNS

\begin{tabular}{|c|c|c|c|c|c|}
\hline Gene & $\begin{array}{l}\text { Nucleotide } \\
\text { change }\end{array}$ & $\begin{array}{l}\text { Amino acid } \\
\text { exchange }\end{array}$ & $\begin{array}{l}\text { dbSNP } \\
\text { name }\end{array}$ & $\begin{array}{l}\text { Status (patient } \\
\text { number) }\end{array}$ & References \\
\hline \multirow[t]{4}{*}{ NPHS2 } & c.954T >C & p.Ala318Ala & rs1410592 & $\operatorname{Hom}(1), \operatorname{Het}(9)$ & $\begin{array}{l}\text { (Karle et } \\
\text { al. 2002) }\end{array}$ \\
\hline & c. $1206 \mathrm{C}>\mathrm{G}$ & 3UTR & rs1410591 & $\operatorname{Hom}(2), \operatorname{Het}(6)$ & $\begin{array}{l}\text { (Dusel et } \\
\text { al. 2005) }\end{array}$ \\
\hline & IVS3 $-46 \mathrm{C}>\mathrm{T}$ & - & rs12401711 & $\operatorname{Het}(5)$ & $\begin{array}{l}\text { (Aucella et } \\
\text { al. 2005) }\end{array}$ \\
\hline & IVS3 $-21 \mathrm{C}>\mathrm{T}$ & - & rs12401708 & $\operatorname{Het}(5)$ & $\begin{array}{l}\text { (Aucella et } \\
\text { al. 2005) }\end{array}$ \\
\hline NPHS1 & c. $3315 \mathrm{G}>\mathrm{A}$ & p.Ser1105Ser & rs2071327 & $\operatorname{Hom}(1), \operatorname{Het}(3)$ & $\begin{array}{l}\text { (Shi et al. } \\
\text { 2005) }\end{array}$ \\
\hline CRB2 & c. $2259 \mathrm{C}>\mathrm{T}$ & p.Ala753Val & - & $\operatorname{Hom}(1)$ & this study \\
\hline
\end{tabular}



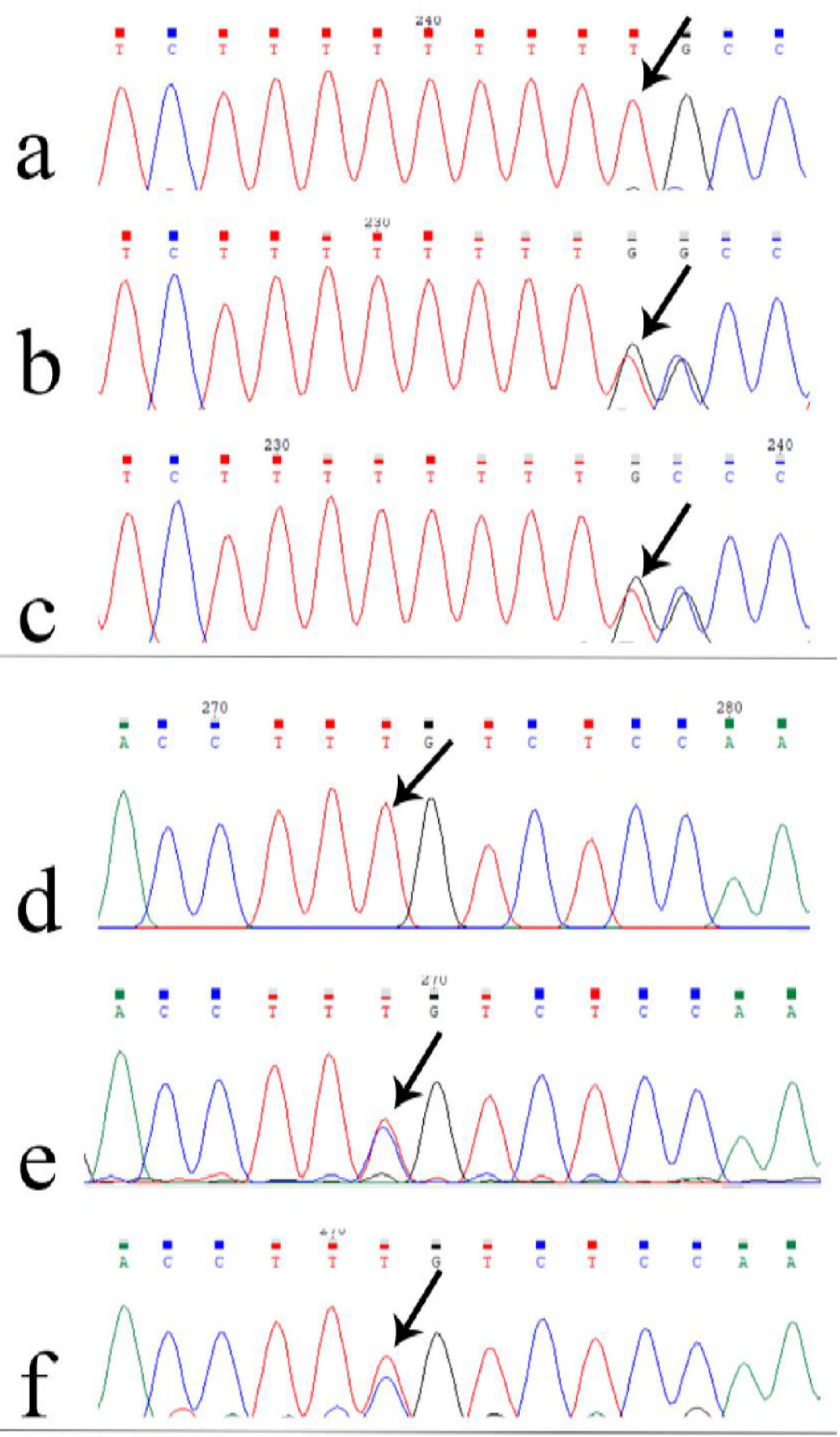

Fig 1. Found mutations in exon 4 of patients and parents. L156fsx166 (a, b and c) -

p.168R $>C(\mathrm{~d}, \mathrm{e}$ and $\mathrm{f})$ 


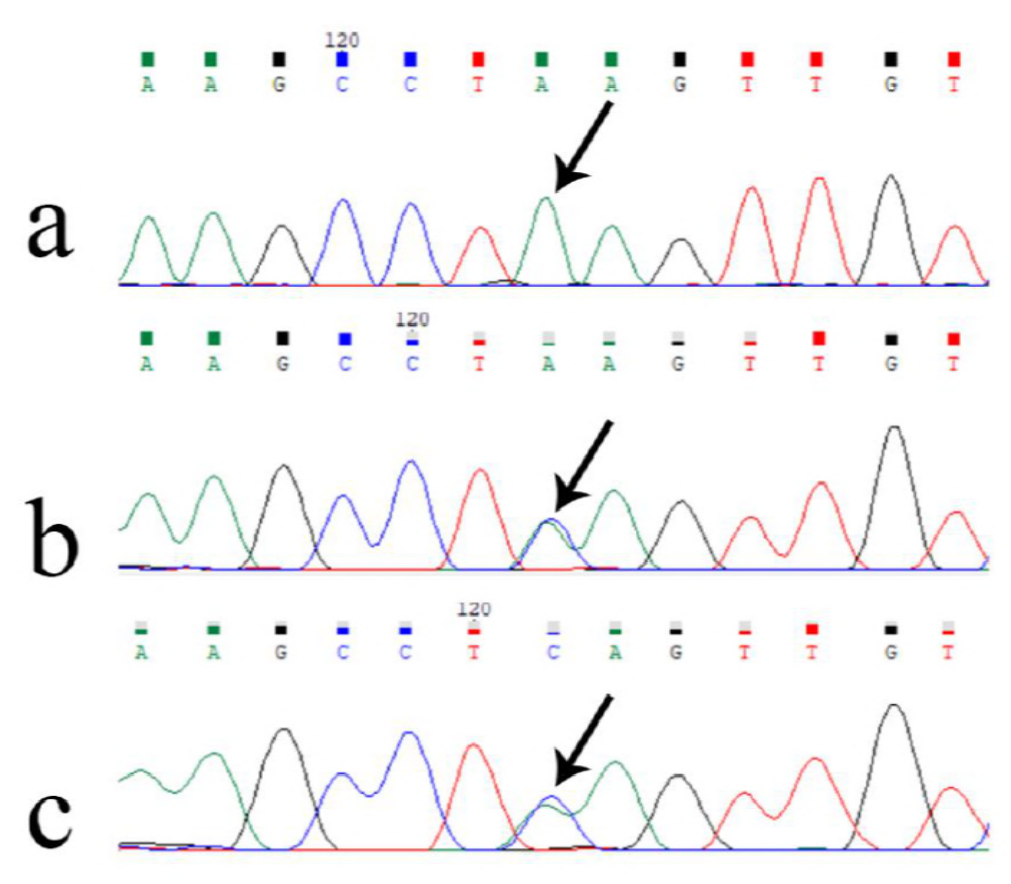

Fig 2. Novel mutation in FAT1 (a) and her parents (b and c)

\section{DISCUSSION}

Idiopathic nephrotic syndrome (INS) is a common clinical condition displaying genetic heterogeneity and significant phenotypic variability (Davin 2016; Bierzynska et al. 2017; Bullich et al. 2015; Sen et al. 2017). It can be caused by many single-gene mutations in both recessive (NPHS1, NPHS2, SMARCAL1, FAT1 and CRB2) and dominant inheritance forms (caused by genes such as WT1 and TRPC6).

Recessive mutations in NPHS1 and NPHS2 cause severe clinical features of early-onset NS and progress to ESRD, either during infancy or throughout childhood. Whereas, Hereditary autosomaldominant NS is rare, occurring mostly in juvenile and adult familial cases(Ha 2017).

NPHS2 mutations have been reported as the most common cause of childhood onset in autosomal recessive SRNS (Sadowski et al. 2015; Guaragna et al. 2015; Tasic et al. 2015). The most frequent renal histological feature Associated with SRNS is focal segmental glomerulosclerosis 
(FSGS)(Joshi et al. 2013; Liu and Wang 2017). In present study, the pathological manifestation of FSGS was about $44 \%$ in patients in which 4 out of 11patients with FSGS were showing NPHS2 mutation in a homozygous state.

Previous studies claim that incidence of NPHS2 mutations in children may vary according to ethnicity (Thomas et al. 2018; Guaragna et al. 2017). In 2013 Basiratnia et al (Basiratnia et al. 2013) showed that NPHS2 mutations were about $31 \%$, responsible for $57 \%$ and $26 \%$ of sporadic and familial forms of SRNS. In our study, 5 of 25(20\%) carried NPHS2 mutations (40\% familial and $60 \%$ sporadic); both studies among Iranian population are almost consistent with findings of studies performed among American (Ruf et al. 2004a), Turkish (Berdeli et al. 2007), Arabic (AlHamed et al. 2013) and Mexican (Carrasco-Miranda et al. 2013) population. (26\% , 24.7\%, 22\% and $21 \%$ respectively), while is in contrast to those findings among Far East population like Chinese (4.3\%) (Yu et al. 2005), Japanese(4\%) (Ogino et al. 2016) and south Korean children (0\%) (Cho et al. 2008). due to all of these data, we suppose a hypothesis that the incidence of NPHS2 mutations decrease from northwest to southwest .

In present study we identified a known frameshift and a missense mutation in exon 4 of NPHS2 (Leu156Phe, R168C) in 3 patients (Karle et al. 2002; Weber et al. 2004). Previous investigations has been reported Two other mutations within this exon among Iranian population $(\mathrm{R} 168 \mathrm{H}$, D160G) (Ameli et al. 2012; Basiratnia et al. 2013). Although Otoukesh et al, indicated no mutation in exon 5 in 2009, but later 3 pathogenic mutations(V180M, R238S, F185fsX186) in this region were found by Basiratnia and her colleagues in 2013 (Basiratnia et al. 2013),similarly V180M in exon 5 was identified in one of our patient. Moreover, in our study P118L mutation was detected in exon 2 . This missense mutation in podocin seems to be a relatively common NPHS2 mutation as it was found in several conducted studies.(Jaffer et al. 2014; Ruf et al. 2004a; Dincel et al. 2013) Although, Behnam et al reported there are more than $65 \%$ hot spot mutations in exon 8 of NPHS2, no mutation was found in our study within this region. 
Despite the high rate of NPHS2 mutation, no hot spot mutations have been identified for this gene. But according to earlier (Basiratnia et al. 2013) and present study, we recommend NPHS2 especially exons 4 and 5 should be considered as first step genetic approach in children with SRNS. Our finding is in consistent with among the other nations indicating common presence of SNPs within exon 4 and 5.(Berdeli et al. 2007; Karle et al. 2002; Tonna et al. 2008; Kari et al. 2013)

NPHS1 Mutations is another primary important gene associated with congenital nephrotic syndrome (CNS) that manifests within 90 days after birth with SRNS (Kestila et al. 1998). So far more than 200 mutations in NPHS1 have been reported (http://www.hgmd.org/, accessed on 2017). 2 known fin minor and fin major mutations in NPHS1 (within exon 26 and 2 respectively) have been found in majority of children (Yang et al. 2016). a study which was carried out in northwest of Iran by Behbahan et al (Behbahan et al. 2013) in 2013 reveled 6 different mutations in $80 \%$ of SRNS children showed no mutation within these exons. Similar to Brazilian (Guaragna et al. 2015) and polish (Binczak-Kuleta et al. 2014) studies, our result indicated pathogenic mutation neither within these exons among all patients nor in other exons of the cases studied by WES. Due to Behbahan's findings (Behbahan et al. 2013) and our study, we suppose that exon 2 and 26 of NPHS1 gene may not be as causative exons for SRNS in Iranian children.

It is acknowledged that more than 53 genes are associated with SRNS in both recessive and dominant inheritance form (Bierzynska et al. 2014; Sen et al. 2017). Gemma Bullich et al supposed that genetic testing using standard Sanger methods is costly and time consuming, even if only the most frequently mutated genes are analyzed (Bullich et al. 2015) but we think that screening for pathogenic variants in some common genes by this method could be the first cost effective approach. Due to genetic heterogeneity of SRNS, Next step may be employing WES. It is noted although WES cost about $30 \%$ more but it leads to identification of new diseasecausing mutations covering all genes associated with SRNS (Wang et al. 2017). 
In our study, through evaluation of WES data in patient 16, known R764Q mutation was found in SMARCAL1 gene, a transcription factor express in podocyte(Antignac 2005). This mutation is related to a disorder known as Schimke immune-osseous dysplasia (SIOD) showing SRNS, short stature and immunedeficiency (Lowik et al. 2009; Boerkoel et al. 2002). Finding a putative mutation using WES method in this case helped us diagnose a disease which its symptoms overlap with SRNS.

Another gene involved in SRNS is FAT1 which Loss of function mutations in this gene results in decreased cell adhesion and migration in fibroblasts and podocytes (Gee et al. 2016). Most of previous studies describe the role of FAT1 heterozygous mutations in some cancers (Morris et al. 2013; Comprehensive genomic characterization of head and neck squamous cell carcinomas 2015), whereas Heon Yung Gee and collogues in 2016 reported 4 different homozygous variant as a causative factor for glomerulotubular nephropathies such as NS (Gee et al. 2016). We here identified a novel recessive variant Q3524K in FAT1 as causing SRNS in a 10 years girl from consanguine parent. This potentially pathogenic variant was evaluated by some predictive tools including SIFT, Polyphen and Mutation Assessor. However to confirm its pathogenicity some functional and in vitro investigations are needed.

Mutations in the WT1 gene, encoding the Wilms' tumor 1 protein, which typically lead to DenysDrash syndrome or Frasier syndrome, can also cause SRNS Type 4 (Chernin et al. 2010; MillerHodges 2016; Hall et al. 2015) .

Exon 8 and 9 of this gene has been considered as one the most prominent implicated genes in SRNS (Mucha et al. 2006; Sen et al. 2017). Clinical manifestation of patient 18 showed an affected girl with congenital and sporadic CNS/SRNS. In this index, WES analysis revealed one homozygous R205C mutation in exon 7, which was a de novo mutation in a hot spot region (Lipska et al. 2014). Our findings are in consistent with previous reports identifying WT1 
mutation mostly in girls, within hot spot regions of WT1 gene (exons 5, 6, 7, 8 and 9) and often in de novo state (Kumar et al. 2016; Lowik et al. 2009) .

The low rate of mutation frequency in WT1 gene of our study (4\%) is similar to some reports by Ruf and his collogues(Ruf et al. 2004b), cho et al (Cho et al. 2008) and Alharthi et al (Alharthi et al. 2017)( $6.9 \%, 5.7 \%$ and 5\% respectively)but is less than reports of MUCKA study(8.9\%) (Mucha et al. 2006) and more than the finding related to Indian children(1.7\%). Although, mutation rate of WT1 is low but patients carrying WT1 mutations represent in early onset with more severe phenotype and congenital form of SRNS.

In overall, SRNS cause $15 \%$ of all chronic kidney disease. In our study, we noticed the interesting data that positive family history of Kidney stone were existed in 16 out of 25(64\%) patients. This finding triggered a hypothesis in our mind that this factor may increase the risk of NS significantly, although to prove its accuracy, more samples and further investigations should be performed.

\section{Conclusion}

In summary, this is the first and largest study among Iranian population with different ethnic origins that investigates causative variants associated with SRNS through screening both common genes (NPHS1 and NPHS2) and whole exome study. Among 25 patients who underwent for PCR sequencing for all exons of NPHS2, 5 patients carried a mutation causing disease, suggesting that NPHS2 especially exons 4 and 5 of this gene should be considered as the first step genetic approach in children with SRNS. For the first time in this country, 3 known variant were detected in WT1, SMARCAL1 and CRB2, significantly a novel variant were identified in FAT1 gene.

Because of the heterogeneous clinical and pathological spectrum, a molecular diagnosis based on sequencing is required. Identification of mutations causing SRNS is of importance, not only for therapeutic considerations but also for genetic counseling. 


\section{ACKNOWLEDGMENTS}

This study was approved and supported by grant no. 96-03-208-31481 by Research Deputy, IUMS.

We gratefully thank Dr.Ali Gharavi for conducting WES and his technical support (Colombia

University Medical Center, IGM Institute for Genomic Medicine, Hemer Health Science).

Refrence:

Al-Hamed, M.H., E. Al-Sabban, H. Al-Mojalli, N. Al-Harbi, E. Faqeih et al., 2013 A molecular genetic analysis of childhood nephrotic syndrome in a cohort of Saudi Arabian families. J Hum Genet 58 (7):480-489.

Alharthi, A.A., A. Gaber, M.W. AbuKhatwah, A.M. Almalki, A.A. Muzallef et al., 2017 Mutational analysis of NPHS2 and WT1 genes in Saudi children with nephrotic syndrome. Current Pediatric Research 21 (1).

Ameli, S., M. Mazaheri, A. Zare-Shahabadi, F. Ozaltin, F. Asgarian et al., 2012 NPHS2 gene mutation in an Iranian family with familial steroid-resistant nephrotic syndrome. Nefrologia 32 (5):674-676.

Antignac, C., 2005 Molecular basis of steroid-resistant nephrotic syndrome. Nefrologia 25 Suppl 2:25-28.

Aucella, F., P. De Bonis, G. Gatta, L.A. Muscarella, M. Vigilante et al., 2005 Molecular analysis of NPHS2 and ACTN4 genes in a series of 33 Italian patients affected by adult-onset nonfamilial focal segmental glomerulosclerosis. Nephron Clin Pract 99 (2):c31-36.

Basiratnia, M., M. Yavarian, S. Torabinezhad, and A. Erjaee, 2013 NPHS2 gene in steroid-resistant nephrotic syndrome: prevalence, clinical course, and mutational spectrum in South-West Iranian children. Iran J Kidney Dis 7 (5):357-362.

Behbahan, A.G., B. Poorshiri, F. Mortazavi, M.S. Khaniani, and S.M. Derakhshan, 2013 NPHS1 gene mutations in children with Nephrotic Syndrome in northwest Iran. Pak J Biol Sci 16 (17):882-886.

Berdeli, A., S. Mir, O. Yavascan, E. Serdaroglu, M. Bak et al., 2007 NPHS2 (podicin) mutations in Turkish children with idiopathic nephrotic syndrome. Pediatr Nephrol 22 (12):2031-2040.

Bierzynska, A., H.J. McCarthy, K. Soderquest, E.S. Sen, E. Colby et al., 2017 Genomic and clinical profiling of a national nephrotic syndrome cohort advocates a precision medicine approach to disease management. Kidney Int 91 (4):937-947.

Bierzynska, A., and M. Saleem, 2017 Recent advances in understanding and treating nephrotic syndrome. F1000Res 6:121.

Bierzynska, A., K. Soderquest, and A. Koziell, 2014 Genes and podocytes - new insights into mechanisms of podocytopathy. Front Endocrinol (Lausanne) 5:226.

Binczak-Kuleta, A., J. Rubik, M. Litwin, M. Ryder, K. Lewandowska et al., 2014 Retrospective mutational analysis of NPHS1, NPHS2, WT1 and LAMB2 in children with steroid-resistant focal segmental glomerulosclerosis - a single-centre experience. Bosn J Basic Med Sci 14 (2):89-93.

Boerkoel, C.F., H. Takashima, J. John, J. Yan, P. Stankiewicz et al., 2002 Mutant chromatin remodeling protein SMARCAL1 causes Schimke immuno-osseous dysplasia. Nat Genet 30 (2):215-220.

Bullich, G., D. Trujillano, S. Santin, S. Ossowski, S. Mendizabal et al., 2015 Targeted next-generation sequencing in steroid-resistant nephrotic syndrome: mutations in multiple glomerular genes may influence disease severity. Eur J Hum Genet 23 (9):1192-1199. 
Carrasco-Miranda, J.S., R. Garcia-Alvarez, R.R. Sotelo-Mundo, O. Valenzuela, M.A. Islas-Osuna et al., 2013 Mutations in NPHS2 (podocin) in Mexican children with nephrotic syndrome who respond to standard steroid treatment. Genet Mol Res 12 (2):2102-2107.

Chernin, G., V. Vega-Warner, D.S. Schoeb, S.F. Heeringa, B. Ovunc et al., 2010 Genotype/phenotype correlation in nephrotic syndrome caused by WT1 mutations. Clin J Am Soc Nephrol 5 (9):16551662.

Cho, H.Y., J.H. Lee, H.J. Choi, B.H. Lee, I.S. Ha et al., 2008 WT1 and NPHS2 mutations in Korean children with steroid-resistant nephrotic syndrome. Pediatr Nephrol 23 (1):63-70.

Comprehensive genomic characterization of head and neck squamous cell carcinomas. 2015 Nature 517 (7536):576-582.

Davin, J.C., 2016 The glomerular permeability factors in idiopathic nephrotic syndrome. Pediatr Nephro/ 31 (2):207-215.

Dincel, N., S. Mir, A. Berdeli, I.K. Bulut, and B. Sozeri, 2013 Does NPHS1 polymorphism modulate P118I mutation in NPHS2? Saudi J Kidney Dis Transp/ 24 (6):1210-1213.

Dusel, J.A.E., K.P. Burdon, P.J. Hicks, G.A. Hawkins, D.W. Bowden et al., 2005 Identification of podocin (NPHS2) gene mutations in African Americans with nondiabetic end-stage renal disease. Kidney Int 68 (1):256-262.

Gee, H.Y., C.E. Sadowski, P.K. Aggarwal, J.D. Porath, T.A. Yakulov et al., 2016 FAT1 mutations cause a glomerulotubular nephropathy. Nat Commun 7:10822.

Guaragna, M.S., A. Lutaif, A.T. Maciel-Guerra, V.M.S. Belangero, G. Guerra-Junior et al., 2017 NPHS2 Mutations: A Closer Look to Latin American Countries. Biomed Res Int 2017:7518789.

Guaragna, M.S., A.C. Lutaif, C.S. Piveta, M.L. Souza, S.R. de Souza et al., 2015 NPHS2 mutations account for only $15 \%$ of nephrotic syndrome cases. BMC Med Genet 16:88.

Ha, T.S., 2017 Genetics of hereditary nephrotic syndrome: a clinical review. Korean J Pediatr 60 (3):55-63.

Hall, G., R.A. Gbadegesin, P. Lavin, G. Wu, Y. Liu et al., 2015 A novel missense mutation of Wilms' Tumor 1 causes autosomal dominant FSGS. J Am Soc Nephrol 26 (4):831-843.

Haraldsson, B., J. Nystrom, and W.M. Deen, 2008 Properties of the glomerular barrier and mechanisms of proteinuria. Physiol Rev 88 (2):451-487.

Hinkes, B.G., B. Mucha, C.N. Vlangos, R. Gbadegesin, J. Liu et al., 2007 Nephrotic syndrome in the first year of life: two thirds of cases are caused by mutations in 4 genes (NPHS1, NPHS2, WT1, and LAMB2). Pediatrics 119 (4):e907-919.

Huber, T.B., M. Simons, B. Hartleben, L. Sernetz, M. Schmidts et al., 2003 Molecular basis of the functional podocin-nephrin complex: mutations in the NPHS2 gene disrupt nephrin targeting to lipid raft microdomains. Hum Mol Genet 12 (24):3397-3405.

Jaffer, A., W. Unnisa, D.S. Raju, and P. Jahan, 2014 NPHS2 mutation analysis and primary nephrotic syndrome in southern Indians. Nephrology (Carlton) 19 (7):398-403.

Joshi, S., R. Andersen, B. Jespersen, and S. Rittig, 2013 Genetics of steroid-resistant nephrotic syndrome: a review of mutation spectrum and suggested approach for genetic testing. Acta Paediatr 102 (9):844-856.

Kari, J.A., S.M. El-Desoky, M. Gari, K. Malik, V. Vega-Warner et al., 2013 Steroid-resistant nephrotic syndrome: impact of genetic testing. Ann Saudi Med 33 (6):533-538.

Karle, S.M., B. Uetz, V. Ronner, L. Glaeser, F. Hildebrandt et al., 2002 Novel mutations in NPHS2 detected in both familial and sporadic steroid-resistant nephrotic syndrome. J Am Soc Nephrol 13 (2):388-393.

Kestila, M., U. Lenkkeri, M. Mannikko, J. Lamerdin, P. McCready et al., 1998 Positionally cloned gene for a novel glomerular protein--nephrin--is mutated in congenital nephrotic syndrome. Mol Cell 1 (4):575-582.

Kumar, A.S., R. Srilakshmi, S. Karthickeyan, K. Balakrishnan, R. Padmaraj et al., 2016 Wilms' tumour 1 gene mutations in south Indian children with steroid-resistant nephrotic syndrome. Indian J Med Res 144 (2):276-280.

Lipska, B.S., B. Ranchin, P. Iatropoulos, J. Gellermann, A. Melk et al., 2014 Genotype-phenotype associations in WT1 glomerulopathy. Kidney Int 85 (5):1169-1178. 
Liu, J., and W. Wang, 2017 Genetic basis of adult-onset nephrotic syndrome and focal segmental glomerulosclerosis. Front Med 11 (3):333-339.

Lovric, S., H. Fang, V. Vega-Warner, C.E. Sadowski, H.Y. Gee et al., 2014 Rapid detection of monogenic causes of childhood-onset steroid-resistant nephrotic syndrome. Clin J Am Soc Nephrol 9 (6):11091116.

Lowik, M.M., P.J. Groenen, E.N. Levtchenko, L.A. Monnens, and L.P. van den Heuvel, 2009 Molecular genetic analysis of podocyte genes in focal segmental glomerulosclerosis--a review. Eur J Pediatr 168 (11):1291-1304.

Mekahli, D., A. Liutkus, B. Ranchin, A. Yu, L. Bessenay et al., 2009 Long-term outcome of idiopathic steroidresistant nephrotic syndrome: a multicenter study. Pediatr Nephrol 24 (8):1525-1532.

Miller-Hodges, E., 2016 Clinical Aspects of WT1 and the Kidney. Methods Mol Biol 1467:15-21.

Morris, L.G., A.M. Kaufman, Y. Gong, D. Ramaswami, L.A. Walsh et al., 2013 Recurrent somatic mutation of FAT1 in multiple human cancers leads to aberrant Wnt activation. Nat Genet 45 (3):253-261.

Mucha, B., F. Ozaltin, B.G. Hinkes, K. Hasselbacher, R.G. Ruf et al., 2006 Mutations in the Wilms' tumor 1 gene cause isolated steroid resistant nephrotic syndrome and occur in exons 8 and 9 . Pediatr Res 59 (2):325-331.

Ogino, D., T. Hashimoto, M. Hattori, N. Sugawara, Y. Akioka et al., 2016 Analysis of the genes responsible for steroid-resistant nephrotic syndrome and/or focal segmental glomerulosclerosis in Japanese patients by whole-exome sequencing analysis. J Hum Genet 61 (2):137-141.

Ruf, R.G., A. Lichtenberger, S.M. Karle, J.P. Haas, F.E. Anacleto et al., 2004a Patients with mutations in NPHS2 (podocin) do not respond to standard steroid treatment of nephrotic syndrome. J Am Soc Nephrol 15 (3):722-732.

Ruf, R.G., M. Schultheiss, A. Lichtenberger, S.M. Karle, I. Zalewski et al., 2004b Prevalence of WT1 mutations in a large cohort of patients with steroid-resistant and steroid-sensitive nephrotic syndrome. Kidney Int 66 (2):564-570.

Sadowski, C.E., S. Lovric, S. Ashraf, W.L. Pabst, H.Y. Gee et al., 2015 A single-gene cause in $29.5 \%$ of cases of steroid-resistant nephrotic syndrome. J Am Soc Nephrol 26 (6):1279-1289.

Santin, S., R. Garcia-Maset, P. Ruiz, I. Gimenez, I. Zamora et al., 2009 Nephrin mutations cause childhoodand adult-onset focal segmental glomerulosclerosis. Kidney Int 76 (12):1268-1276.

Sen, E.S., P. Dean, L. Yarram-Smith, A. Bierzynska, G. Woodward et al., 2017 Clinical genetic testing using a custom-designed steroid-resistant nephrotic syndrome gene panel: analysis and recommendations. J Med Genet 54 (12):795-804.

Shi, Y., J. Ding, J.C. Liu, H. Wang, and D.F. Bu, 2005 [NPHS1 mutations in a Chinese family with congenital nephrotic syndrome]. Zhonghua Er Ke Za Zhi 43 (11):805-809.

Tasic, V., Z. Gucev, and M. Polenakovic, 2015 Steroid Resistant Nephrotic Syndrome-Genetic Consideration. Pril (Makedon Akad Nauk Umet Odd Med Nauki) 36 (3):5-12.

Thomas, M.M., M.S. Abdel-Hamid, N.N. Mahfouz, and E.E. Ghobrial, 2018 Genetic mutation in Egyptian children with steroid-resistant nephrotic syndrome. J Formos Med Assoc 117 (1):48-53.

Tonna, S.J., A. Needham, K. Polu, A. Uscinski, G.B. Appel et al., 2008 NPHS2 variation in focal and segmental glomerulosclerosis. BMC Nephrol 9:13.

Wang, Y., X. Dang, Q. He, Y. Zhen, X. He et al., 2017 Mutation spectrum of genes associated with steroidresistant nephrotic syndrome in Chinese children. Gene 625:15-20.

Weber, S., O. Gribouval, E.L. Esquivel, V. Moriniere, M.J. Tete et al., 2004 NPHS2 mutation analysis shows genetic heterogeneity of steroid-resistant nephrotic syndrome and low post-transplant recurrence. Kidney Int 66 (2):571-579.

Yang, F., Y. Chen, Y. Zhang, L. Qiu, Y. Chen et al., 2016 Novel NPHS1 gene mutations in a Chinese family with congenital nephrotic syndrome. J Genet 95 (1):161-166.

Yu, Z., J. Ding, J. Huang, Y. Yao, H. Xiao et al., 2005 Mutations in NPHS2 in sporadic steroid-resistant nephrotic syndrome in Chinese children. Nephrol Dial Transplant 20 (5):902-908. 